Volume 4, Nomor 2, 2017, hlm 107-120

p-ISSN: $2302-6073$, e-ISSN: 2579 - 4809

Journal Home Page: http://journal.uin-alauddin.ac.id

DOI: https://doi.org/10.24252/nature.v4i2a3

\title{
TIPOLOGI BUKAAN PADA RUMAH TRADISIONAL BUGIS DI BENTENG SOMBA OPU MAKASSAR
}

\author{
Marwati $^{1}$, Sri Andriani ${ }^{2}$ \\ Arsitektur UIN Alauddin Makassar \\ e-mail:*1mar.ambodalle@gmail.com
}

\begin{abstract}
Abstrak_ Perkembangan zaman saat ini menyebabkan pengaplikasian penggunaan bukaan pada rumah-rumah masyarakat bugis mengalami perubahan, hal itu dapat dilihat pada bentuk, ukuran, bahan, dan ornamen pada bukaan seperti pintu, jendela dan ventilasi pada rumah-rumah masyarakat bugis saat ini yang mulai mengikuti zaman. Penelitian ini bertujuan untuk mengidentifikasi tipologi bentuk bukaan seperti pintu, jendela, dan ventilasi pada rumah tradisional bugis yang berada dalam kawasan Benteng Somba Opu sebelum mengalami perubahan bentuk. Dari segi ukuran, bahan dan ornamen yang digunakan pada rumah. Objek yang dikaji adalah sembilan rumah tradisional dari etnis bugis, meliputi rumah tradisional Bugis, Luwu, Bone, Wajo, Sidrap, Pinrang, Barru, dan dua rumah tradisional Soppeng dengan menggunakan metode deskriptif dengan analisis crosstabs. Sebagian besar ( $80 \%$ ) bukaan pada rumah bugis tidak mirip antar daerah. Adanya tipologi bentuk bukaan untuk pintu dan jendela didominasi bentuk segiempat kombinasi panil dan krepyak dan bentuk ventilasi segiempat dengan model terbuka. Adanya Kesamaan bahan yang berasal dari material kayu. Terdapat Perbedaan dalam tipologi bentuk bukaan terlihat pada variasi ukuran dan ornament yang digunakan.
\end{abstract}

Kata-kunci : Tipologi, Bugis, Bukaan, Tradisional

\begin{abstract}
The development of the current era led to the application of openings in homes of bugis people to change, it can be seen on the shape, size, materials, and ornaments at openings such as doors, windows and ventilation in homes of today's bugis people who started to follow the times. This study aims to identify the typology of openings such as doors, windows, and ventilation of traditional Bugis houses within the Somba Opu Fortress area before being transformed. In terms of size, materials and ornaments used at home. Objects studied are nine traditional houses of ethnic bugis, covering traditional Bugis, Luwu, Bone, Wajo, Sidrap, Pinrang, Barru, and two traditional Soppeng houses using descriptive methods with crosstabs analysis. Most (80\%) openings in bugis homes are not similar across regions. The typology of openings for doors and windows is dominated by a rectangular combination of panels and blinds and a quadrilateral vent with an open model. The similarity of materials derived from wood materials. Differences in the typology of openings are visible on the size and ornament variations used.
\end{abstract}

Keywords: Typology, Bugis, Openings, Traditional

${ }^{1}$ Dosen Jurusan Teknik Arsitektur UIN Alauddin Makassar

${ }^{2}$ Mahasiswi Jurusan Teknik Arsitektur UIN Alauddin Makassar 


\section{PENDAHULUAN}

Sejarah arsitektur berkaitan dengan bukaan pada bangunan seperti pintu, jendela dan ventilasi. Pintu, jendela dan ventilasi merupakan bukaan pada sebuah dinding di sebuah bangunan yang memasukkan cahaya dan udara ke dalam ruangan. Pintu, jendela dan ventilasi berkembang seiring zaman dan di semua daerah, tetapi tujuan utamanya untuk memasukkan sinar matahari kedalam ruangan. Bukaan merupakan elemen yang dapat memodifikasi iklim luar ke dalam bangunan. (Philips dan Gardner, 2004) dalam Dahniar (2012) :7-12.

Pada masyarakat Bugis, elemen penting pada dinding depan ialah pintu (babang/tange). Pintu diletakkan pada depan, karena jumlah tiang pada bagian depan berjumlah 5 (lima). Hal yang spesifik pada penyelesaian pintu adalah adanya dinding pembatas setinggi lutut pada bagian bawah. Fungsi penyelesaian bukaan pintu demikian bertujuan untuk melindungi anak-anak agar tidak jatuh ke bawah karena sebagian besar lokasi rumah menempati daerah rawa. Bukaan lain adalah jendela (tellongeng) yang mempunyai fungsi untuk memasukkan cahaya dan udara ke dalam bangunan. Perletakannya pada dinding di antara dua tiang. Jendela menunjukkan strata sosial pemilik rumah, dimana jumlah jendela tiga buah menunjukkan rakyat biasa sedangkan jumlah jendela tujuh buah menunjukkan bangsawan. Pada jendela biasanya terdapat hiasan berupa ukiran atau terali dari kayu dengan jumlah bilangan ganjil. Jumlah terali 3-5 buah untuk rakyat biasa sedangkan 7-9 buah untuk rumah bangsawan. (Abidin, 1969) dalam Dahniar (2012):7-12. Pada bagian samping terdapat bukaan yang berupa lobang ventilasi dan pemasangan papan kayu secara longgar untuk mengalirkan udara silang dari arah berbeda dari bukaan jendela depan. Bukaan ini sangat sederhana namun tepat guna dan memiliki corak yang sama berupa bentuk geometri segi enam sebanyak tiga buah.

Aplikasi penggunaan bukaan pada rumah tradisional Bugis dapat kita lihat pada rumahrumah adat tradisional yang berada pada Kompleks Miniatur Budaya Sulawesi Selatan di Benteng Somba Opu. Kompleks miniatur ini memiliki koleksi 27 bangunan rumah tradisional yang mewakili empat etnis di Sulawesi Selatan dan Sulawesi Barat, yaitu Makassar, Bugis, Toraja, dan Mandar. Terdiri dari 23 rumah yang dibangun oleh setiap pemerintah daerah dan empat rumah yang dibangun oleh pemerintah provinsi. Penelitian ini berusaha untuk mengidentifikasi ragam tipologi bentuk bukaan seperti pintu, jendela dan ventilasi yang digunakan pada rumah-rumah tradisional suku Bugis yang berada di Benteng Somba Opu, Makassar, Sulawesi Selatan.

\section{METODOLOGI}

Penelitian ini menggunakan metode deskriptif dengan pendekatan kuantitatif dan kualitatif dimana pendekatan pada kedua metode ini berbeda. Pada metode kualitatif digunakan dengan cara mempelajari beberapa literatur berupa teori-teori yang membahas mengenai ragam bentuk bukaan seperti pintu, jendela dan ventilasi dari segi ukuran, bahan dan ornament pada bangunan rumah adat tradisional dari etnis Bugis yang berada di Benteng Somba Opu, dan mempelajari beberapa jurnal yang sudah pernah melakukan penelitian serupa. Sedangkan untuk kuantitif dilakukan pada saat melakukan observasi di lapangan untuk mengukur dimensi bukaan. Objek yang dikaji adalah sembilan rumah tradisional dari etnis bugis, meliputi rumah tradisional Bugis, 
Luwu, Bone, Wajo, Sidrap, Pinrang, Barru, dan dua rumah tradisional Soppeng yang berada di Benteng Somba Opu.

Metode analisis data dalam mengetahui tipologi bukaan pintu, jendela, dan ventilasi yaitu berupa analisis crosstabs (tabulasi silang). Adapun Lokasi sampel dapat dilihat pada Gambar berikut :

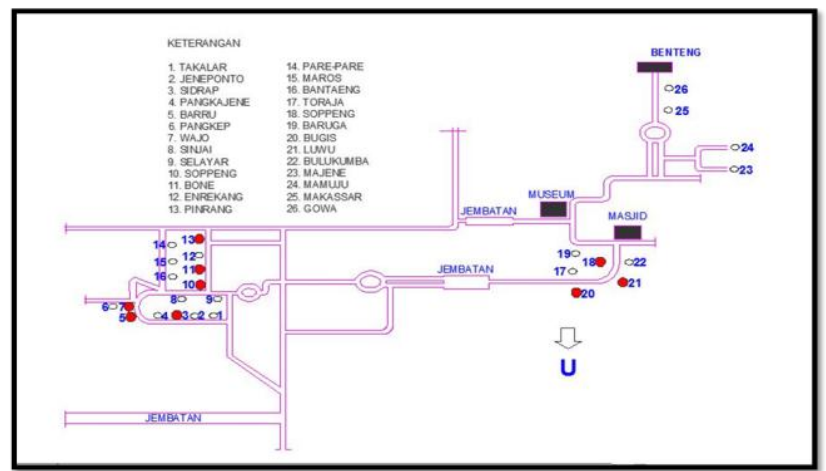

Gambar 1. Letak objek penelitian rumah tradisional Bugis dalam Kompleks Miniatur Budaya Sulawesi Selatan di Benteng Somba Opu.

\section{HASIL DAN PEMBAHASAN}

\section{BUGIS}

Tabel 1. Bukaan pada rumah tradisional Bugis

\begin{tabular}{|c|c|c|c|c|}
\hline \multicolumn{2}{|c|}{ 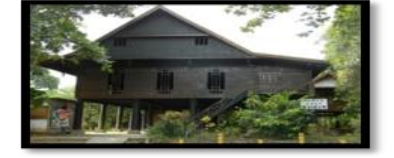 } & \multicolumn{3}{|c|}{$\begin{array}{l}\text { Rumah adat Bugis tidak hanya unik karena bentuknya namun juga } \\
\text { karena landasan filosofinya. Yaitu menggambarkan } 3 \text { hal yakni botting langi } \\
\text { (dunia atas), ale kawa (dunia tengah) dan awa bola (dunia bawah). }\end{array}$} \\
\hline & PINTU & JENDELA & VENTILASI & GAGASAN \\
\hline BENTUK & & (HID) & & $\begin{array}{l}\text { - Terdapat pembatas pada bagian bawah pintu. } \\
\text { - Daun pintu berjumalah } 1 . \\
\text { - Pintu panil. } \\
\text { - Jendela permanen dengan terali vertikal. } \\
\text { - Tanpa daun jendela. } \\
\text {-Ventilasi pada bagian bawah jendela dengan } \\
\text { terali/ kisi-kisi/ jalusi krepyak vertikal. }\end{array}$ \\
\hline UKURAN & & & & \\
\hline ORNAMEN & Tidak memiliki & Tidak memiliki & Tidak memiliki & Tidak memiliki ornamen \\
\hline BAHAN & Kayu & Kayu & Kayu & Menggunakan kayu bayam \\
\hline
\end{tabular}

Sumber: Data survei, 2017 


\section{LUWU}

Tabel 1. Bukaan pada rumah tradisional Luwu

\begin{tabular}{|c|c|c|c|c|}
\hline$S E$ & 78 & $\begin{array}{l}\text { bentuk } \\
\text { jendela } \\
\text { Hal ini } \\
\text { siang h } \\
\text { Rumah } \\
\text { tingkat } \\
\text { bubung }\end{array}$ & $\begin{array}{l}\text { esain Bentuk } \\
\text { a hampir mirip } \mathrm{J} \\
\text { an pintu pada ru } \\
\text { ikarenakan untu } \\
\text {, sehingga ukurar } \\
\text { dat Luwu status } \\
\text { pada rumah ters } \\
\text { yang menandak }\end{array}$ & $\begin{array}{l}\text { umah Adat Luwu dan Rumah Adat Bugis } \\
\text { aitu berbentuk persegi empat. Desain bentuk } \\
\text { mah adat Luwu ini hampir sama panjangnya. } \\
\text { x memaksimalkan penghawaan alami disaat } \\
\text { jendela dibuat sebesar pintu. } \\
\text { sosialnya bisa kita lihat dengan banyaknya } \\
\text { but, biasaya rumah adat Luwu terdiri dari 3-5 } \\
\text { n status social sang pemiliki rumah. }\end{array}$ \\
\hline & PINTU & JENDELA & VENTILASI & GAGASAN \\
\hline BENTUK & & & $\begin{array}{l}\text {-Tidak terdapat } \\
\text { ventilasi khusus. }\end{array}$ & $\begin{array}{l}\text { - Terdapat pembatas pada bagian bawah pintu. } \\
\text { - Daun pintu berjumalah } 2 \text {. } \\
\text { - Pintu dari kombinasi panil dan jalusi/krepyak. } \\
\text {-Jendela ayun kombinasi dari panil dan } \\
\text { jalusi/krepyak. } \\
\text {-Tidak terdapat ventilasi khusus, hanya saja pada } \\
\text { pintu dan jendela terdapat jalusi/ krepyak yang } \\
\text { dapat berfungsi sebagai ventilasi }\end{array}$ \\
\hline UKURAN & & & $\begin{array}{l}\text {-Tidak terdapat } \\
\text { ventilasi khusus. }\end{array}$ & \\
\hline ORNAMEN & Tidak memiliki & Tidak memiliki & Tidak memiliki & Tidak memiliki ornamen \\
\hline BAHAN & Kayu & Kayu & - & Menggunakan kayu jati \\
\hline
\end{tabular}

Sumber: Data survei, 2017

\section{BONE}

Tabel 1. Bukaan pada rumah tradisional Bone

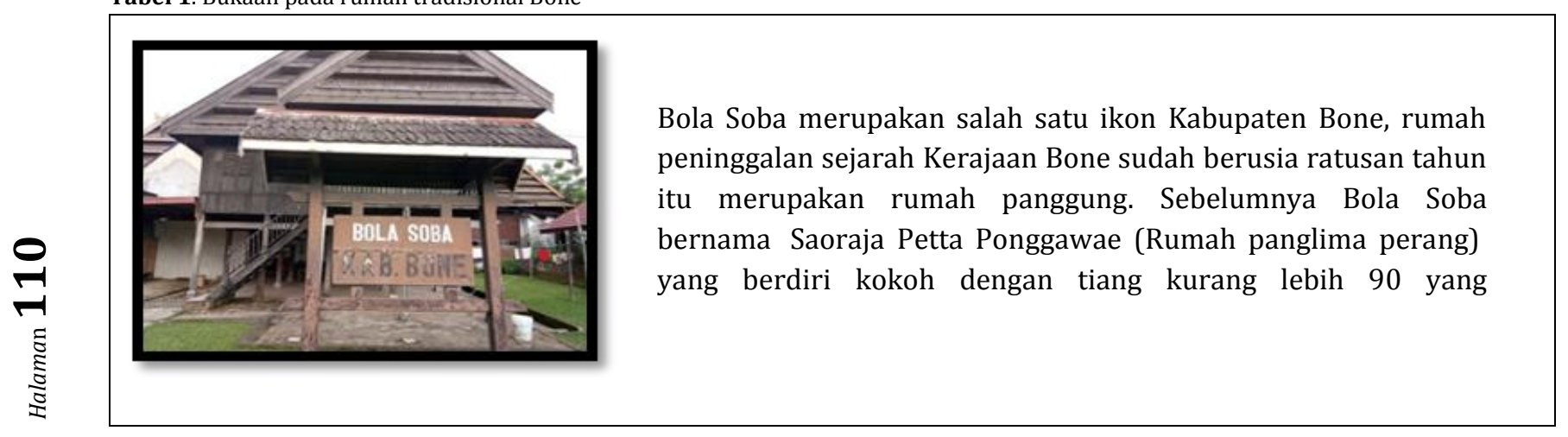




\begin{tabular}{|c|c|c|c|c|}
\hline & PINTU & JENDELA & VENTILASI & GAGASAN \\
\hline BENTUK & & & $\begin{array}{l}\text {-Tidak terdapat } \\
\text { ventilasi khusus, }\end{array}$ & $\begin{array}{l}\text { - Daun pintu berjumlah } 2 . \\
\text { - Pintu dari panil kayu. } \\
\text {-Jendela ayun kombinasi dari panil dan } \\
\text { jalusi/krepyak. } \\
\text {-Tidak terdapat ventilasi khusus, hanya saja pada } \\
\text { pintu dan jendela terdapat jalusi/ krepyak yang } \\
\text { dapat berfungsi sebagai ventilasi. }\end{array}$ \\
\hline UKURAN & & & $\begin{array}{l}\text {-Tidak terdapat } \\
\text { ventilasi khusus, }\end{array}$ & \\
\hline ORNAMEN & Tidak memiliki & Tidak memiliki & Tidak memiliki & Tidak memiliki ornamen \\
\hline BAHAN & Kayu & Kayu & - & Menggunakan kayu bayam \\
\hline
\end{tabular}

Sumber: Data survei, 2017

\section{WAJO}

Tabel 1. Bukaan pada rumah tradisional Wajo

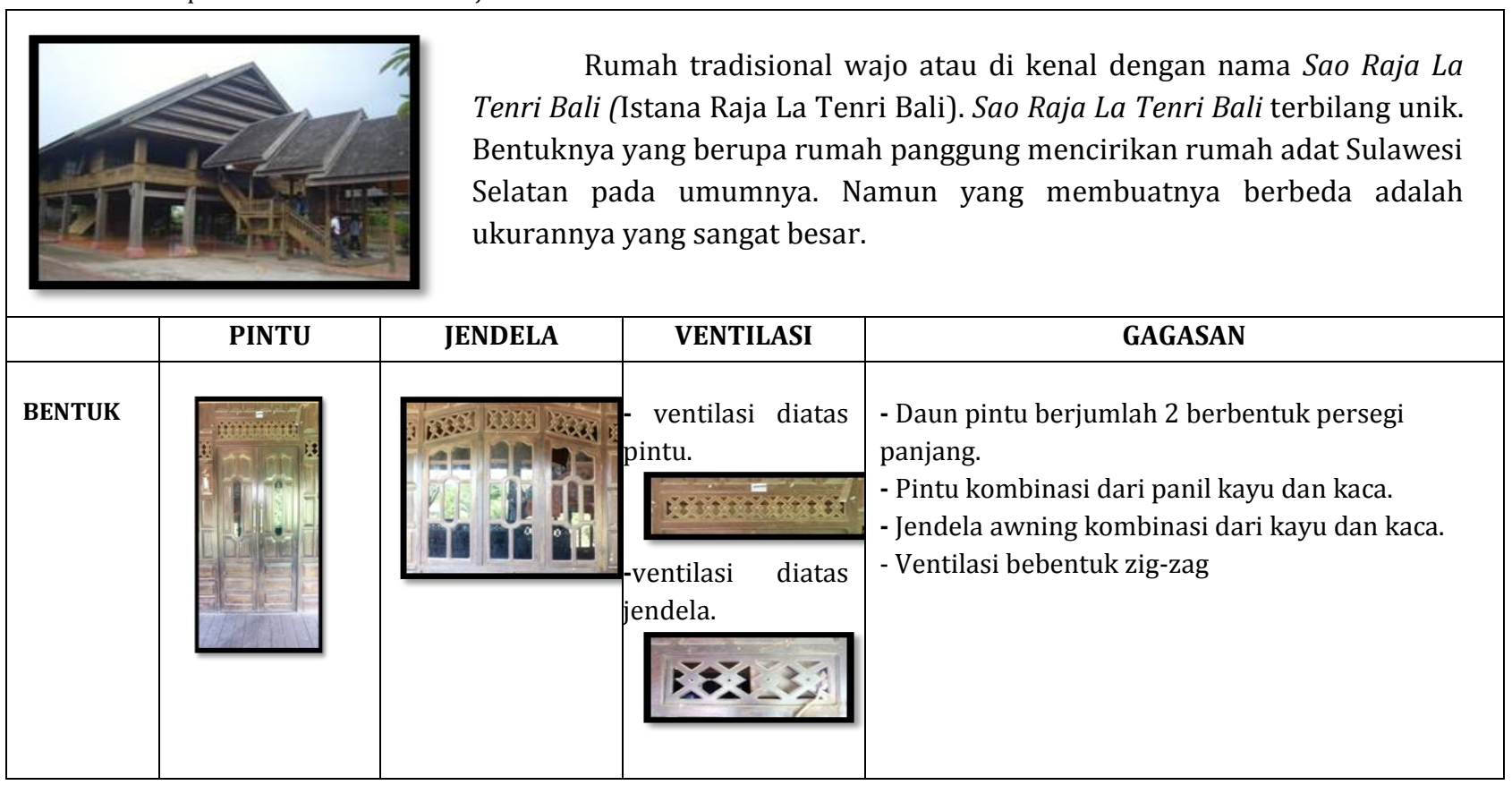




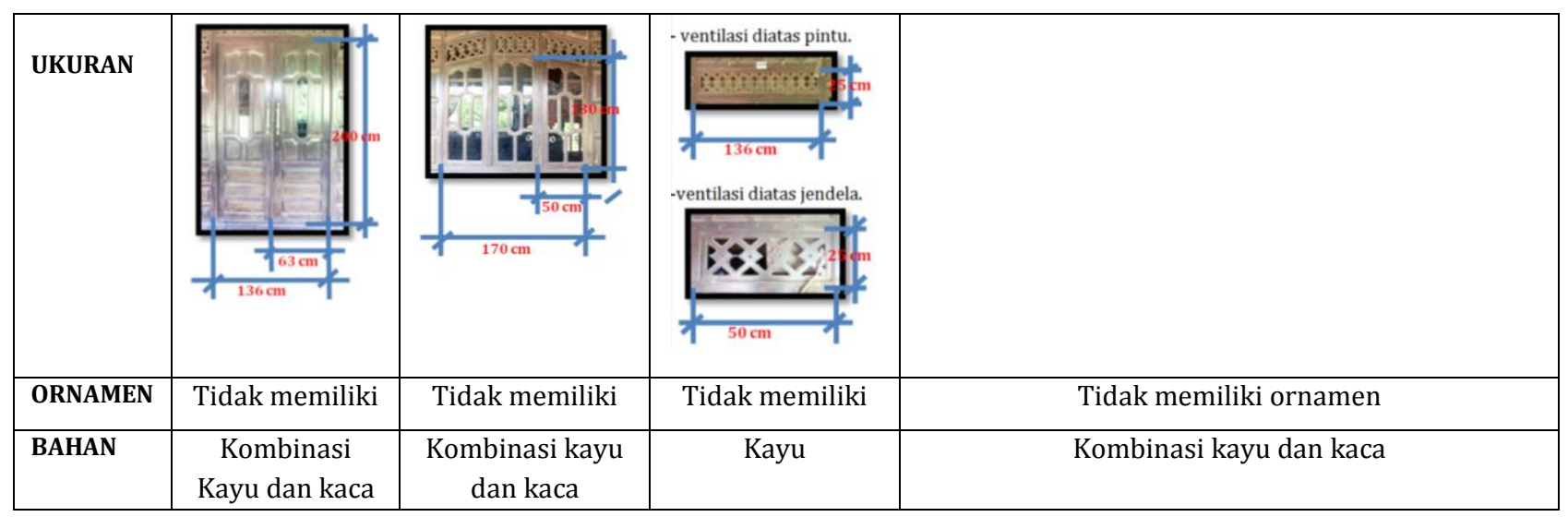

Sumber: Data survei, 2017

\section{SIDRAP}

Tabel 1. Bukaan pada rumah tradisional Sidrap

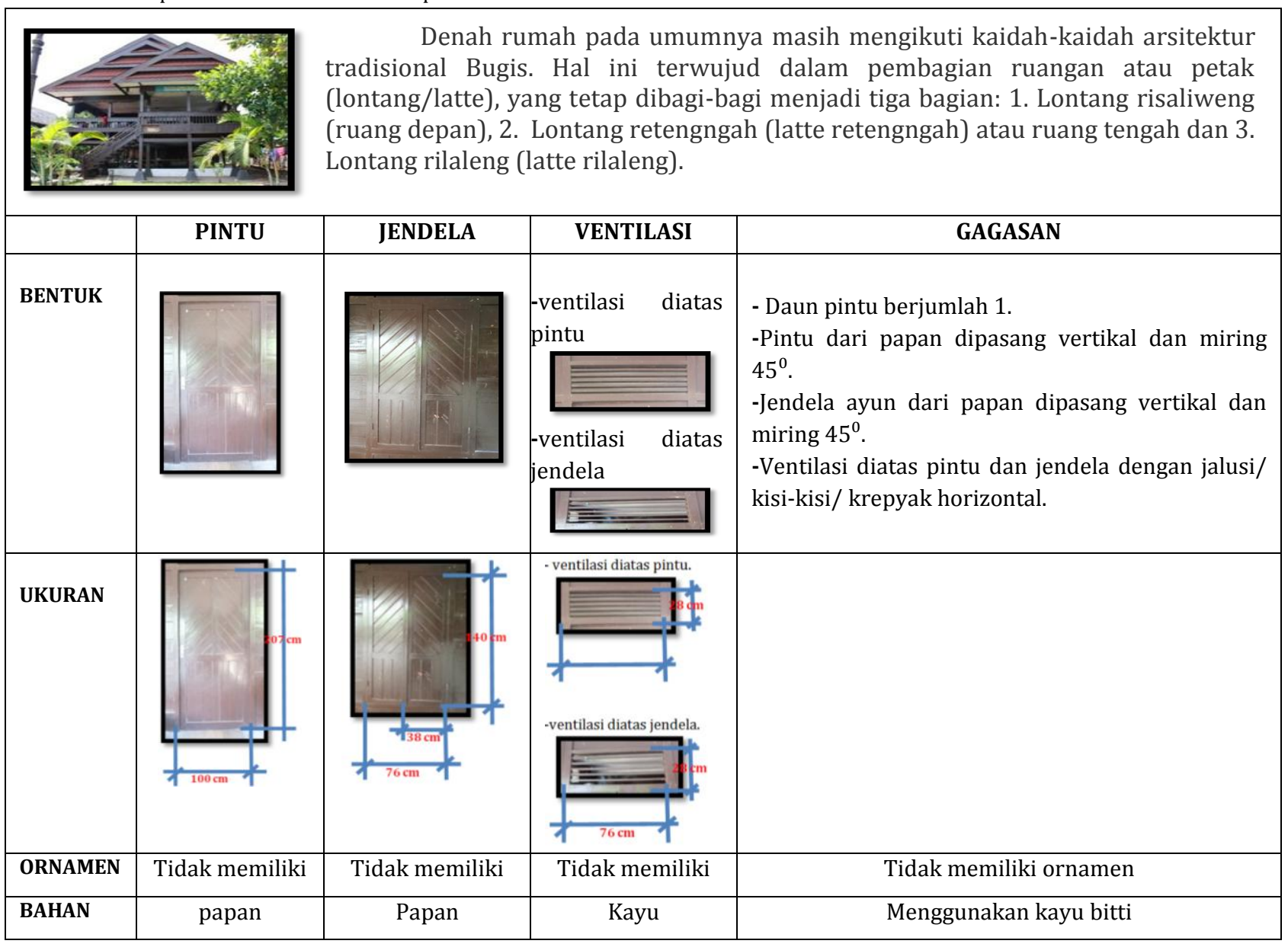

Sumber: Data survei, 2017 


\section{PINRANG}

Tabel 1. Bukaan pada rumah tradisional Pinrang

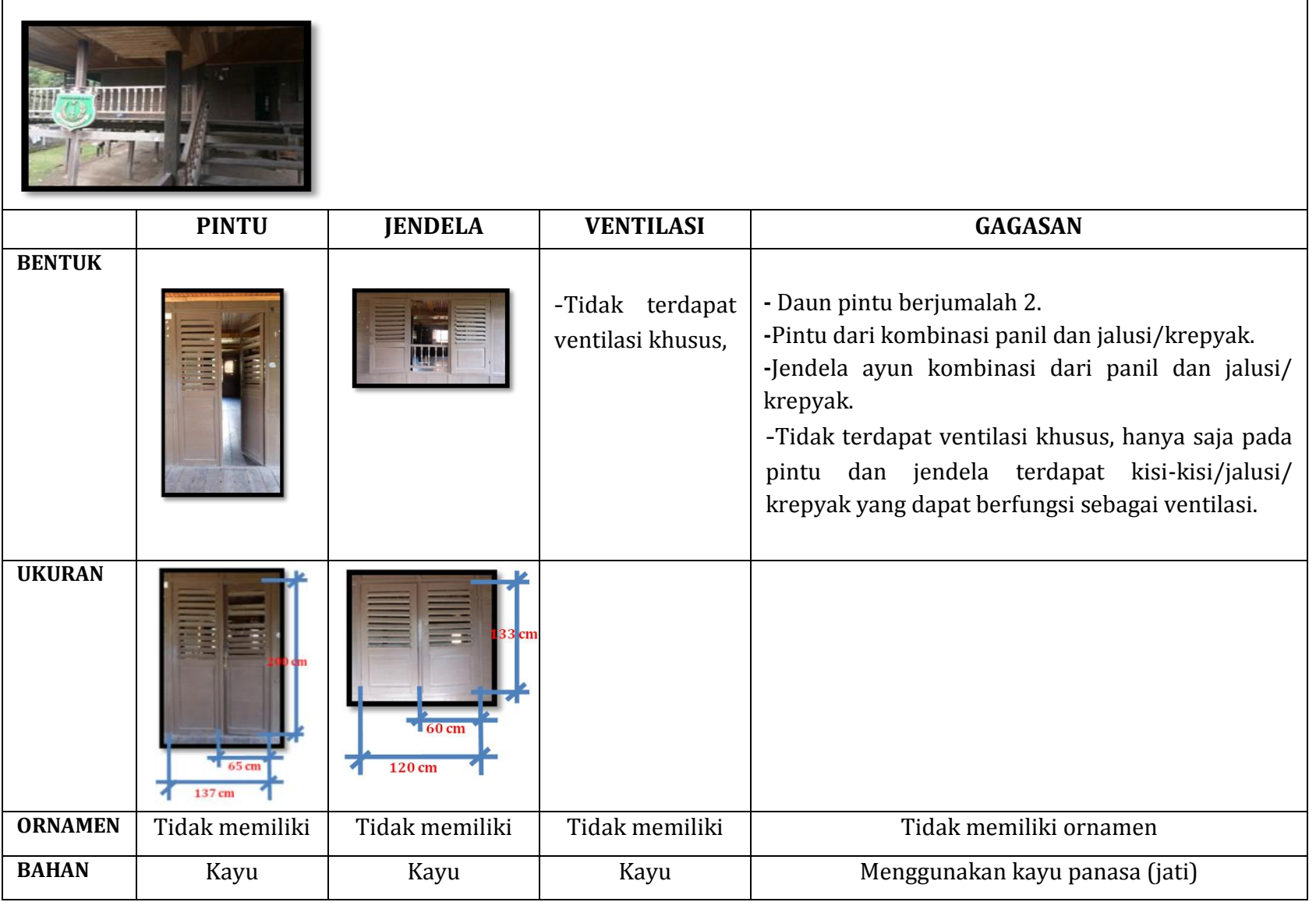

Sumber: Data survei, 2017

\section{BARRU}

Tabel 1. Bukaan pada rumah tradisional Barru

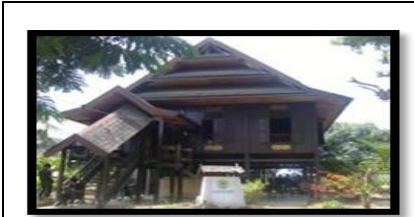

Rumah tradisional Barru yang terletak di kawasan benteng somba opu ini mempunyai 3 timpa laja, dengan pintu dan jendela yang memiliki 2 daun, ventilasi yang berada di atas pintu dan jendelanya dan juga memiliki ornamen (bunga parengreng) yang berwarna kuning keemasan yang berada pada atas ventilasi dan bagian bawah pintu dan jendela.

\begin{tabular}{|c|c|c|c|c|}
\hline & PINTU & JENDELA & VENTILASI & GAGASAN \\
\hline BENTUK & $\lim _{x \rightarrow-1}$ & $\begin{array}{l}402 \times 1 \\
1 \\
\end{array}$ & 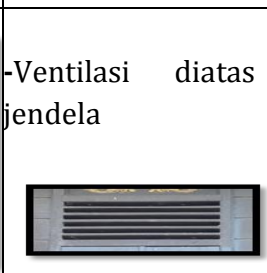 & $\begin{array}{l}\text { - Daun pintu berjumlah } 2 . \\
\text { - pintu dari panil kayu. } \\
\text { - jendela ayun dari panil kayu. } \\
\text {-ventilasi diatas jendela dengan jalusi/ kisi-kisi/ } \\
\text { krepyak horizontal. }\end{array}$ \\
\hline
\end{tabular}




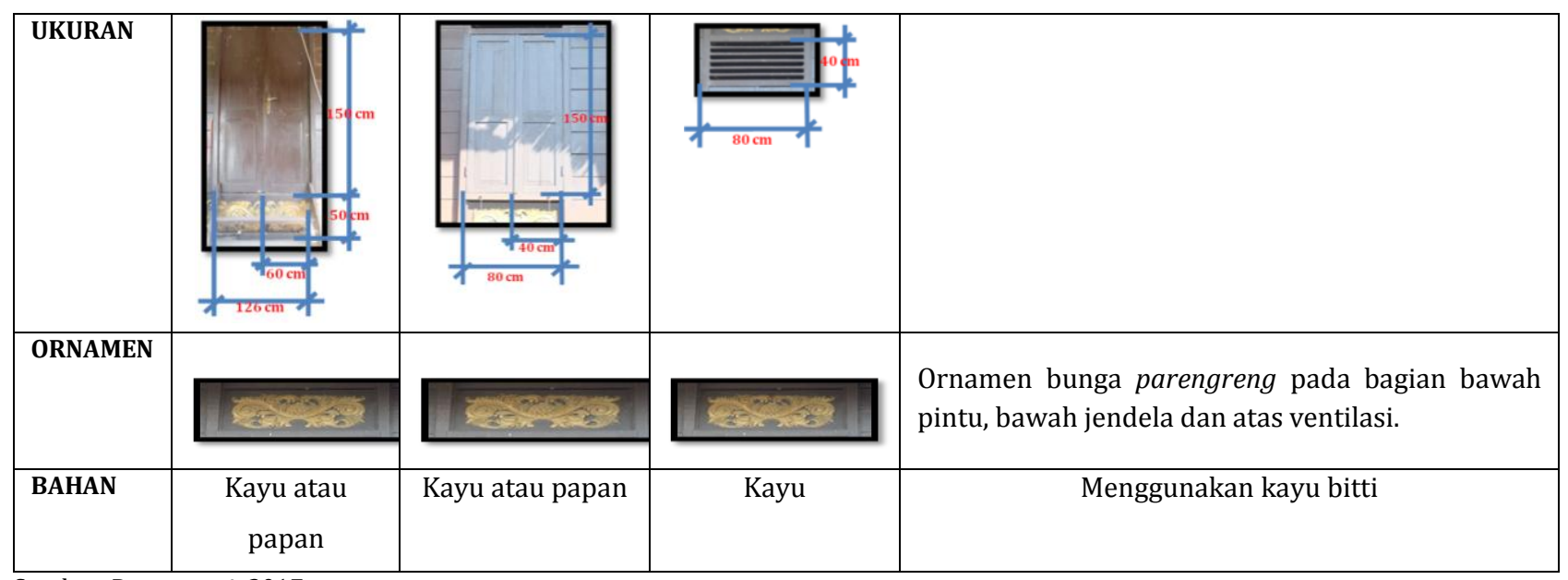

Sumber: Data survei, 2017

\section{SOPPENG (BOLA SOBA)}

Tabel 1. Bukaan pada rumah tradisional Soppeng (Bola Soba)

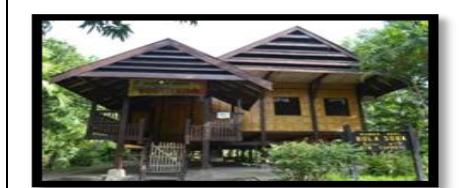

Rumah tradisional Barru yang terletak di kawasan benteng somba opu ini merupakan rumah panggung yang umumnya menggunakan bahan kombinasi kayu dan bambu, yang memiliki 1 daun pintu dan tanpa menggunakan daun pada iendelanva hanva saia menggunakan ialusi kavu.

\begin{tabular}{|c|c|c|c|c|}
\hline & PINTU & JENDELA & VENTILASI & GAGASAN \\
\hline BENTUK & & & $\begin{array}{l}\text { - Ventilasi di atas } \\
\text { pintu } \\
\text { ifillititi }\end{array}$ & $\begin{array}{l}\text { - Terdapat pembatas pada bagian bawah pintu. } \\
\text { - Daun pintu berjumalah } 1 \text { yang dibuat dari bahan } \\
\text { bambu. } \\
\text { - Jendela permanen dengan terali vertikal. } \\
\text { - Ventilasi pada bagian atas pintu dengan jalusi/ } \\
\text { kisi-kisi/ krepyak vertikal. }\end{array}$ \\
\hline UKURAN & & & & \\
\hline ORNAMEN & Tidak memiliki & Tidak memiliki & Tidak memiliki & Tidak memiliki ornamen \\
\hline BAHAN & $\begin{array}{c}\text { Bambu dan } \\
\text { kayu }\end{array}$ & Bambu dan kayu & Bambu dan kayu & Menggunakan bambu dan kayu \\
\hline
\end{tabular}

Sumber: Data survei, 2017 


\section{SOPPENG}

Tabel 9. Bukaan pada rumah tradisional Soppeng

\begin{tabular}{|c|c|c|c|c|}
\hline 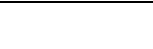 & PINTU & JENDELA & VEBTILASI & GAGASAN \\
\hline BENTUK & & 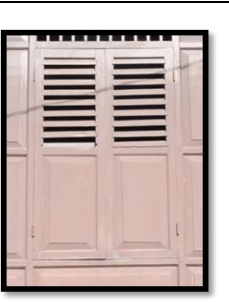 & & $\begin{array}{l}\text { - Daun pintu berjumlah } 1 . \\
\text { - Pintu dari panil kayu. } \\
\text {-Jendela ayun kombinasi dari panil dan jalusi/ } \\
\text { krepyak. } \\
\text {-Ventilasi pada bagian atas pintu dan jendela } \\
\text { dengan jalusi/ kisi-kisi/ krepyak. }\end{array}$ \\
\hline UKURAN & $\left.\left.\left.\right|^{f}\right|^{f}\right|^{\mathrm{cm}}$ & 害害害 & 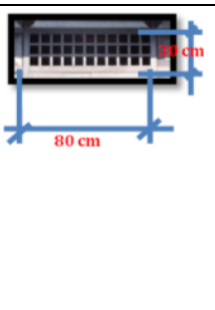 & \\
\hline ORNAMEN & Tidak memiliki & Tidak memiliki & Tidak memiliki & Tidak memiliki ornamen \\
\hline BAHAN & kayu & Kayu & kayu & kayu \\
\hline
\end{tabular}

Sumber: Data survei, 2017

Berdasarkan data tabel diatas diketahui ukuran, bahan dan ornamen pada bukaan, sembilan rumah tradisional bugis (Luwu, Bone, Sidrap, Pinrang, Barru, dan dua rumah tradisional Soppeng) berbentuk segiempat atau persegi panjang, sedangkan dua rumah lainnya (rumah tradisional Bugis dan Wajo) memadukan bentuk segi empat dan lengkung/ setengah lingkaran. Bahan berasal dari kayu, kecuali rumah tradisional Wajo yang telah memadukan bahan kayu dan kaca, serta rumah tradisional Soppeng (bola soba) yang memadukan bambu dan kayu. Dan rumah tradisional Barru yang memiliki ornamen berupa bunga parengreng.

Berdasarkan hasil identifikasi bukaan pada Sembilan objek rumah tradisional Bugis dapat di klasifikasikan berdasarkan bentuk, ukuran, bahan dan ornamen, maka dapat dianalisis sebagai berikut:

\section{A. TIPOLOGI PINTU}

Tabel 10. Klasifikasi Pintu pada rumah tradisional Bugis

\begin{tabular}{|c|c|c|c|c|c|}
\hline NO. & SAMPEL & BENTUK & UKURAN & BAHAN & ORNAMEN \\
\hline 1. & Pintu Rumah tradisional Bugis & $\begin{array}{l}\text {-1 daun pintu } \\
\text { persegi panjang. } \\
\text {-Pintu panil }\end{array}$ & $\begin{array}{l}\mathrm{P}=163 \mathrm{~cm} \\
\mathrm{~L}=198 \mathrm{~cm}\end{array}$ & kayu bayam & $\begin{array}{c}\text { Tidak memiliki } \\
\text { ornamen }\end{array}$ \\
\hline
\end{tabular}




\begin{tabular}{|c|c|c|c|c|c|}
\hline 2. & Pintu Rumah tradisional Luwu & $\begin{array}{c}2 \text { daun pintu } \\
\text { persegi panjang }\end{array}$ & $\begin{array}{l}\mathrm{P}=183 \mathrm{~cm} \\
\mathrm{~L}=129 \mathrm{~cm}\end{array}$ & kayu Jati & $\begin{array}{l}\text { Tidak memiliki } \\
\text { ornamen }\end{array}$ \\
\hline 3. & 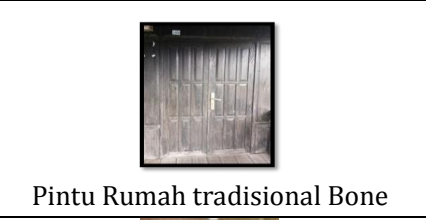 & $\begin{array}{c}2 \text { daun pintu } \\
\text { persegi panjang }\end{array}$ & $\begin{array}{l}\mathrm{P}=184 \mathrm{~cm} \\
\mathrm{~L}=127 \mathrm{~cm}\end{array}$ & kayu bayam & $\begin{array}{l}\text { Tidak memiliki } \\
\text { ornamen }\end{array}$ \\
\hline 4. & Pintu Rumah tradisional Wajo & $\begin{array}{c}2 \text { daun pintu } \\
\text { persegi panjang }\end{array}$ & $\begin{array}{l}\mathrm{P}=200 \mathrm{~cm} \\
\mathrm{~L}=136 \mathrm{~cm}\end{array}$ & $\begin{array}{c}\text { Kombinasi kayu } \\
\text { dan kaca }\end{array}$ & $\begin{array}{l}\text { Tidak memiliki } \\
\text { ornamen }\end{array}$ \\
\hline 5. & Pintu Rumah tradisional Sidrap & $\begin{array}{l}-1 \text { daun pintu } \\
\text { persegi panjang }\end{array}$ & $\begin{array}{l}\mathrm{P}=207 \mathrm{~cm} \\
\mathrm{~L}=100 \mathrm{~cm}\end{array}$ & kayu bayam & $\begin{array}{l}\text { Tidak memiliki } \\
\text { ornamen }\end{array}$ \\
\hline 6. & $\begin{array}{l}\text { Pintu Rumah tradisional Pinrang } \\
\text { Pand }\end{array}$ & $\begin{array}{c}2 \text { daun pintu } \\
\text { persegi panjang }\end{array}$ & $\begin{array}{l}\mathrm{P}=200 \mathrm{~cm} \\
\mathrm{~L}=137 \mathrm{~cm}\end{array}$ & $\begin{array}{c}\text { kayu kayu panasa } \\
\text { (nangka) }\end{array}$ & $\begin{array}{l}\text { Tidak memiliki } \\
\text { ornamen }\end{array}$ \\
\hline 7. & Pintu Rumah tradisional Barru & $\begin{array}{c}2 \text { daun pintu } \\
\text { persegi panjang }\end{array}$ & $\begin{array}{l}\mathrm{P}=150 \mathrm{~cm} \\
\mathrm{~L}=126 \mathrm{~cm}\end{array}$ & kayu bitti & $\begin{array}{l}\text { Memiliki } \\
\text { ornamen }\end{array}$ \\
\hline 8. & Pintu Rumah tradisional Soppeng & $\begin{array}{c}1 \text { daun pintu } \\
\text { persegi panjang }\end{array}$ & $\begin{array}{l}\mathrm{P}=160 \mathrm{~cm} \\
\mathrm{~L}=80 \mathrm{~cm}\end{array}$ & Bambu dan kayu & $\begin{array}{l}\text { Tidak memiliki } \\
\text { ornamen }\end{array}$ \\
\hline 9. & Pintu Rumah tradisional Soppeng & $\begin{array}{c}1 \text { daun pintu } \\
\text { persegi panjang }\end{array}$ & $\begin{array}{c}\mathrm{P}=184 \mathrm{~cm} \\
\mathrm{~L}=80 \mathrm{~cm}\end{array}$ & Kayu/papan & $\begin{array}{l}\text { Tidak memiliki } \\
\text { ornamen }\end{array}$ \\
\hline
\end{tabular}




\begin{tabular}{|c|c|c|c|c|c|}
\hline 10. & KESIMPULAN & $\begin{array}{c}\text { Memiliki 1-2 daun } \\
\text { pintu yang } \\
\text { berbentuk } \\
\text { persegi panjang. }\end{array}$ & $\begin{array}{c}\text { Memiliki ukuran } \\
\text { yang berbeda- } \\
\text { beda }\end{array}$ & $\begin{array}{c}\text { Bahan dari kayu } \\
\text { tradisional } \\
\text { bayam, jati, } \\
\text { nangka, bitti, } \\
\text { Barru yang } \\
\text { memiiki } \\
\text { bambu, dan kaca. } \\
\text { ornamen pada } \\
\text { bagian bawah } \\
\text { pintu. }\end{array}$ & \\
\hline
\end{tabular}

Sumber: Data survei, 2017

\section{B. JENDELA}

Tabel 11. Klasifikasi Pintu pada rumah tradisional Bugis

\begin{tabular}{|c|c|c|c|c|c|}
\hline NO. & SAMPEL & BENTUK & UKURAN & BAHAN & ORNAMEN \\
\hline 1. & Jendela Rumah tradisional Bugis & $\begin{array}{l}\text { - jendela } \\
\text { permanen dengan } \\
\text { terali vertikal. } \\
\text { - tanpa daun } \\
\text { jendela. } \\
\text {-berbentuk dari } \\
\text { gabungan persegi } \\
\text { panjang dan } \\
\text { setengan } \\
\text { lingkaran. }\end{array}$ & $\begin{array}{c}P=176 \mathrm{~cm} \\
L=83 \mathrm{~cm}\end{array}$ & kayu bayam & $\begin{array}{c}\text { Tidak memiliki } \\
\text { ornamen }\end{array}$ \\
\hline 2. & Jendela Rumah tradisional Luwu & $\begin{array}{l}2 \text { daun jendela } \\
\text { dalam } 1 \text { jendela } \\
\text { berbentuk } \\
\text { persegi panjang }\end{array}$ & $\begin{array}{l}\mathrm{P}=250 \mathrm{~cm} \\
\mathrm{~L}=108 \mathrm{~cm}\end{array}$ & kayu Jati & $\begin{array}{c}\text { Tidak memiliki } \\
\text { ornamen }\end{array}$ \\
\hline 3. & $\begin{array}{l}\text { Jendela Rumah tradisional Bone } \\
\text { Jen }\end{array}$ & $\begin{array}{l}2 \text { daun jendela } \\
\text { berbentuk } \\
\text { persegi panjang }\end{array}$ & $\begin{array}{l}\mathrm{P}=136 \mathrm{~cm} \\
\mathrm{~L}=86 \mathrm{~cm}\end{array}$ & kayu bayam & $\begin{array}{c}\text { Tidak memiliki } \\
\text { ornamen }\end{array}$ \\
\hline 4. & 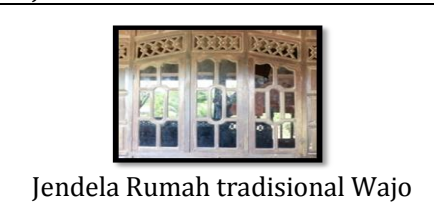 & $\begin{array}{l}3 \text { daun jendela } \\
\text { persegi panjang }\end{array}$ & $\begin{array}{l}P=130 \mathrm{~cm} \\
L=170 \mathrm{~cm}\end{array}$ & $\begin{array}{c}\text { Kombinasi kayu } \\
\text { dan kaca }\end{array}$ & $\begin{array}{c}\text { Tidak memiliki } \\
\text { ornamen }\end{array}$ \\
\hline 5. & Jendela Rumah tradisional Sidrap & $\begin{array}{l}\text {-1 daun jendela } \\
\text { persegi panjang. } \\
\text {-pintu dari papan } \\
\text { dipasang vertikal } \\
\text { dan miring } 45^{\circ} \text {. }\end{array}$ & $\begin{array}{c}P=140 \mathrm{~cm} \\
\mathrm{~L}=76 \mathrm{~cm}\end{array}$ & kayu bayam & $\begin{array}{c}\text { Tidak memiliki } \\
\text { ornamen }\end{array}$ \\
\hline 6. & Jendela Rumah tradisional Pinrang & $\begin{array}{l}2 \text { daun jendela } \\
\text { berbentuk } \\
\text { persegi panjang }\end{array}$ & $\begin{array}{l}\mathrm{P}=133 \mathrm{~cm} \\
\mathrm{~L}=120 \mathrm{~cm}\end{array}$ & $\begin{array}{c}\text { kayu kayu panasa } \\
\text { (jati) }\end{array}$ & $\begin{array}{c}\text { Tidak memiliki } \\
\text { ornamen }\end{array}$ \\
\hline
\end{tabular}




\begin{tabular}{|c|c|c|c|c|c|}
\hline 7. & 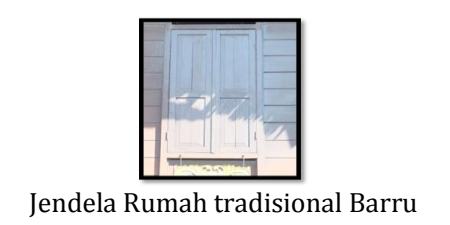 & $\begin{array}{l}2 \text { daun jendela } \\
\text { persegi panjang }\end{array}$ & $\begin{array}{l}\mathrm{P}=150 \mathrm{~cm} \\
\mathrm{~L}=80 \mathrm{~cm}\end{array}$ & kayu bitti & $\begin{array}{l}\text { Memiliki } \\
\text { ornamen }\end{array}$ \\
\hline 8. & Jendela Rumah tradisional Soppeng & $\begin{array}{c}\text { Berbentuk Bujur } \\
\text { sangkar }\end{array}$ & $\begin{array}{l}\mathrm{P}=190 \mathrm{~cm} \\
\mathrm{~L}=90 \mathrm{~cm}\end{array}$ & Bambu dan kayu & $\begin{array}{l}\text { Tidak memiliki } \\
\text { ornamen }\end{array}$ \\
\hline 9. & $\underbrace{}_{\text {Jendela Rumah tradisional Soppeng }}$ & $\begin{array}{l}2 \text { daun jendela } \\
\text { persegi panjang }\end{array}$ & $\begin{array}{l}\mathrm{P}=136 \mathrm{~cm} \\
\mathrm{~L}=86 \mathrm{~cm}\end{array}$ & Kayu/papan & $\begin{array}{l}\text { Tidak memiliki } \\
\text { ornamen }\end{array}$ \\
\hline 10. & KESIMPULAN & $\begin{array}{c}\text { Memiliki 1,2, dan } \\
3 \text { daun jendela } \\
\text { yang berbentuk } \\
\text { persegi panjang. } \\
\text { bujur sangkar, } \\
\text { dan gabungan } \\
\text { antara persegi } \\
\text { panjang dan } \\
\text { setengah } \\
\text { lingkaran. }\end{array}$ & $\begin{array}{c}\text { Memiliki ukuran } \\
\text { yang berbeda- } \\
\text { beda }\end{array}$ & $\begin{array}{c}\text { Bahan dari kayu } \\
\text { bayam, jati, } \\
\text { nangka, bitti, } \\
\text { bambu, dan kaca. }\end{array}$ & $\begin{array}{c}\text { Hanya rumah } \\
\text { tradisional } \\
\text { Barru yang } \\
\text { memiiki } \\
\text { ornamen pada } \\
\text { bagian bawah } \\
\text { jendela. }\end{array}$ \\
\hline
\end{tabular}

Sumber: Data survei, 2017

\section{VENTILASI}

Tabel 12. Klasifikasi Ventilasi pada rumah tradisional Bugis

\begin{tabular}{|c|c|l|c|c|c|}
\hline NO. & SAMPEL & BENTUK & UKURAN & BAHAN & ORNAMEN \\
\hline 1. & Ventilasi Rumah tradisional Bugis & $\begin{array}{l}\text {-Jendela } \\
\text { permanen dengan } \\
\text { terali vertikal. } \\
\text {-Berbentuk dari } \\
\text { gabungan persegi } \\
\text { dan stengan } \\
\text { lingkaran. }\end{array}$ & $\begin{array}{l}\mathrm{P}=176 \mathrm{~cm} \\
\mathrm{~L}=83 \mathrm{~cm}\end{array}$ & $\begin{array}{c}\text { kayu bayam } \\
\text { Tidak memiliki } \\
\text { ornamen }\end{array}$ \\
\hline 2. & Tidak terdapat ventilasi khusus & - & - & - & - \\
\hline 3. & Tidak terdapat ventilasi khusus & - & - & - \\
\hline
\end{tabular}




\begin{tabular}{|c|c|c|c|c|c|}
\hline 4. & $\begin{array}{l}\text { - ventilasi diatas pintu. } \\
\text {-ventilasi diatas jendela. }\end{array}$ & Berbentuk zig-zag & $\begin{array}{l}\text { - Ventilasi diatas } \\
\text { pintu. } \\
\qquad \mathrm{P}=136 \mathrm{~cm} \\
\mathrm{~L}=25 \mathrm{~cm} \\
\text {-Ventilasi diatas } \\
\text { jendela. } \\
\mathrm{P}=50 \mathrm{~cm} \\
\mathrm{~L}=25 \mathrm{~cm}\end{array}$ & kayu & $\begin{array}{l}\text { Tidak memiliki } \\
\text { ornamen }\end{array}$ \\
\hline 5. & $\begin{array}{l}\text { - ventilasi diatas pintu. } \\
\text {-ventilasi diatas jendela. } \\
\text { Ventilasi Rumah tradisional Sidrap }\end{array}$ & $\begin{array}{l}\text { jalusi/ kisi-kisi/ } \\
\text { krepyak } \\
\text { horizontal }\end{array}$ & $\begin{array}{l}\text { - Ventilasi diatas } \\
\text { pintu. } \\
\qquad \mathrm{P}=100 \mathrm{~cm} \\
\mathrm{~L}=28 \mathrm{~cm} \\
\text {-Ventilasi diatas } \\
\text { jendela. } \\
\mathrm{P}=76 \mathrm{~cm} \\
\mathrm{~L}=28 \mathrm{~cm}\end{array}$ & kayu bayam & $\begin{array}{l}\text { Tidak memiliki } \\
\text { ornamen }\end{array}$ \\
\hline 6. & $\begin{array}{l}\text { Tidak terdapat ventilasi } \\
\text { khusus }\end{array}$ & - & - & - & - \\
\hline 7. & -ventilasi diatas jendela. & $\begin{array}{l}\text { jalusi/ kisi-kisi/ } \\
\text { krepyak } \\
\text { horizontal }\end{array}$ & $\begin{array}{l}\mathrm{P}=80 \mathrm{~cm} \\
\mathrm{~L}=40 \mathrm{~cm}\end{array}$ & kayu bitti & Memiliki ornamen \\
\hline 8. & $\begin{array}{c}\text { - ventilasi diatas pintu. } \\
\text { Jendela Rumah tradisional Soppeng } \\
\text { (Bola Soba) }\end{array}$ & $\begin{array}{l}\text { jalusi/ kisi-kisi/ } \\
\text { krepyak vertikal }\end{array}$ & $\begin{array}{l}\mathrm{P}=120 \mathrm{~cm} \\
\mathrm{~L}=50 \mathrm{~cm}\end{array}$ & Bambu dan kayu & $\begin{array}{l}\text { Tidak memiliki } \\
\text { ornamen }\end{array}$ \\
\hline 9. & $\begin{array}{l}\text {-Ventilasi pada bagian atas pintu } \\
\text { dan jendela }\end{array}$ & $\begin{array}{l}\text { jalusi/ kisi-kisi/ } \\
\text { krepyak vertikal } \\
\text { dan horizontal }\end{array}$ & $\begin{array}{l}P=136 \mathrm{~cm} \\
\mathrm{~L}=86 \mathrm{~cm}\end{array}$ & Kayu & $\begin{array}{l}\text { Tidak memiliki } \\
\text { ornamen }\end{array}$ \\
\hline 10. & KESIMPULAN & $\begin{array}{l}\text { berbentuk persesi } \\
\text { panjang, zig-zg, } \\
\text { jalusi horizontal } \\
\text { dan vertial, dan } \\
\text { gabungan persegi } \\
\text { dan stengan } \\
\text { lingkaran. }\end{array}$ & $\begin{array}{c}\text { Memiliki ukuran } \\
\text { yang berbeda- } \\
\text { beda }\end{array}$ & $\begin{array}{l}\text { Bahan dari kayu } \\
\text { bayam, jati, } \\
\text { nangka, bitti, dan } \\
\text { bambu. }\end{array}$ & $\begin{array}{l}\text { Hanya rumah } \\
\text { tradisional Barru } \\
\text { yang memiiki } \\
\text { ornamen pada } \\
\text { bagian atas } \\
\text { ventilasi. }\end{array}$ \\
\hline
\end{tabular}

Sumber: Data survei, 2017

Aspek ukuran, bahan, dan ornamen pada bukaan seperti pintu, jendela, dan ventilasi pada rumah tradisional Bugis dalam Kawasan Budaya di Benteng Somba Opu Makassar yaitu pada pintu rata-rata memiliki 1-2 daun pintu yang berbentuk persegi panjang dengan ukuran yang berbeda-beda, kombinasi panil dan jalusi/kisi-kisi pada rumah Luwu dan Pinrang, kombinasi kayu dan kaca pada rumah Wajo, kombinasi bambu dan kayu pada rumah Bola Soba Soppeng, 
panil pada rumah Bugis, Bone, Barru dan Soppeng. dan papan pada rumah Sidrap, berdasarkan bahan umumnya menggunakan kayu kecuali rumah tradisional Wajo yang menggunakan kombinasi kayu dan kaca selain itu juga pada rumah tradisional Bola Soba Soppeng yang menggunakan kombinasi bambu dan kayu. Pada jendela rata-rata memiliki 1,2 dan 3 daun jendela yang berbentuk persegi panjang, bujur sangkar, kombinasi persegi panjang dan setengah lingkaran, dengan ukuran yang berbeda-beda. dari kombinasi panil dan jalusi, papan yang dipasang vertikal dan miring 45 derajat pada rumah sidrap, kombinasi kayu dan kaca, dan kombinasi bambu dan kayu. Pada ventilasi berdasarkan bentuk Jalusi/kisi-kisi/krepyak Vertikal yaitu pada rumah Bugis dan Bola Soba Soppeng, Jalusi/kisi-kisi/krepyak horizontal yaitu pada rumah Barru dan Sidrap, berbentuk zig-zag yaitu pada rumah Wajo dan Ventilasi dengan jalusi/kisi-kisi kombinasi Horizontal dan vertikal yaitu pada rumah tradisional soppeng. dan hanya 1 rumah yang memiliki ornamen (Bunga Parengreng) pada bagian bawah pintu, bawah jendela dan bagian atas ventilasi.

\section{KESIMPULAN}

Berdasarkan Sembilan objek yang diteliti dapat disimpulkan bahwa Sebagian besar ( 80 \%) bukaan pada rumah bugis tidak mirip antar daerah. Adanya tipologi bentuk bukaan untuk pintu dan jendela didominasi bentuk segiempat kombinasi panil dan krepyak dan bentuk ventilasi segiempat dengan model terbuka. Adanya Kesamaan bahan yang berasal dari material kayu. Terdapat Perbedaan dalam tipologi bentuk bukaan terlihat pada variasi ukuran dan ornament yang digunakan.

\section{DAFTAR PUSTAKA}

Ching, F.K dan Adams, C (2001). Ilustrasi Konstruksi Bangunan. Jakarta : Erlangga

Dahniar."Tipologi Bentuk Jendela pada Rumah Tradisional Bugis di Taman Miniatur Sulawesi Selatan,Benteng Somba Opu Makassar".TEMU ILMIAH IPLBI 2013.

Atiza Nurhuzna. (2012). "Transformasi Fungsi Dan Bentuk Arsitektur Bugis-Makassar di Pesisir Pantai Buti Merauke".

Hamka, dkk. 2015. "Karakteristik Orientasi Rumah Tradisional (Bola Ugi) Di Dusun Kajuara Kabupaten Bone Sulawesi Selatan". Langkau Betang, Vol .2 : 2.

Raziq Hasan." Perubahan Bentuk dan Fungsi Arsitektur Tradisional Bugis di Kawasan Pesisir Kamal Muara, Jakarta Utara. 